mediastudies.press • Social Media \& the Self: An Open Reader

\title{
Are We Already Living in Virtual Reality?
}

Joshua Rothman

Published on: Mar 26, 2018

DOI: $10.32376 / 3 f 8575 c b . a 3506 d 5 b$

License: Creative Commons Attribution-NonCommercial 4.0 International License (CC-BYNC 4.0). 
THOMAS METZINGER HAD his first out-of-body experience when he was nineteen. He was on a ten-week meditation retreat in the Westerwald, a mountainous area near his home, in Frankfurt. After a long day of yoga and meditation, he had a slice of cake and fell asleep. Then he awoke, feeling an itch on his back. He tried to scratch it, but couldn't-his arm seemed paralyzed. He tried to force the arm to move, and, somehow, this shifted him up and out of his body, so that he seemed to be floating above himself. Gazing out into the room, he was both amazed and afraid. He heard someone else breathing and, in a panic, looked around for an intruder. Only much later did he realize that the breathing had been his.

At the time, in the early nineteen-eighties, Metzinger was a philosophy student researching the mind-body problem at the Johann Wolfgang Goethe-Universität. During the postwar years, Theodor Adorno and Max Horkheimer had made the university's Institute for Social Research-the Frankfurt School-a center of neoMarxist thought, and the campus remained a politically radical place. In Britain and America, philosophers, computer scientists, psychologists, and neuroscientists were working together to reconceive the mind as a purely physical system created by the brain. In Metzinger's department, such theories were denounced as anti-human and "proto-fascist." Metzinger considered himself a radical-he had waist-length hair, and was proud to have been teargassed while protesting the U.S. military-but also a rationalist. Immersing himself in the work of the Anglophone philosophers, he'd eventually become convinced that his soul was made by his brain. He was, therefore, doubly shocked by his out-of-body experience, which had seemed irrevocably real. Could materialism be wrong? Could consciousness exist immaterially, outside of the body? He admonished himself: "How arrogant I have been!”...

\section{continue reading}

\section{OUTBOUND LINK}

"Are We Already Living in Virtual Reality?" (Joshua Rothman, The New Yorker, March 26, 2018)

METERED PAYWALL (4 free articles per month) 